\title{
SOUTH AFRICAN IRON AND STEEL INDUSTRIAL EVOLUTION: AN INDUSTRIAL ENGINEERING PERSPECTIVE
}

\author{
R.A. Dondofema ${ }^{1 \#}$, S. Matope ${ }^{1 *} \&$ G. Akdogan ${ }^{2}$
}

\section{ARTICLE INFO}

\section{Article details}

Submitted by authors

Accepted for publication 10 Sep 2017

Available online

Contact details

Corresponding author

smatope@sun.ac.za

Author affiliations

1 Department of Industrial

Engineering, Stellenbosch

University, South Africa

2 Department of Process Engineering, Stellenbosch University, South Africa

\# The author was enrolled for an M Eng. (Research) Industrial Engineering degree in the Department of Industrial Engineering, Stellenbosch University

DOI

http://dx.doi.org/10.7166/28-4-1683

ABSTRACT

The paper focuses on the evolution of the South African iron and steel industry from the industrial engineering perspective. The earliest ironmaking in South Africa dates to the fifth century CE; but the major evolution of the industry began in 1882 and, by the year 1934 , steel production from native ore was in full swing. The study highlights the major developments in South Africa's iron and steel industry, and ends by exploring the extent of the application of industrial engineering techniques to published research into the steel industry.

\section{OPSOMMING}

Hierdie artikel fokus op die evolusie van die Suid-Afrikaanse ysteren staalindustrie vanuit 'n bedryfsingenieurswese perspektief. Die vroegste yster produksie in Suid-Afrika dateer terug na die vyfde eeu VC, maar die hoofsaaklike ontwikkeling vind sy oorsprong in 1882 en staalproduksie vanaf ystererts was teen 1934 in volle swang. Hierdie studie lig die hooftrekke van ontwikkelings in Suid-Afrika se yster- en staalindustrie uit en sluit af deur die omvang van die toepassing van bedryfsingenieurswesetegnieke tot gepubliseerde navorsing in hierdie industrie te ondersoek.

\section{GENESIS OF IRON AND STEEL INDUSTRY IN SOUTH AFRICA}

The period of the Iron Age extends from 200 CE to 1840 [1]. Iron tools have been crucial to economic development and industrialisation. In South Africa, the roots of the iron and steel industry date back to the fifth century CE [2], with the smelting of iron lumps in pit furnaces. Since then it has evolved to the reduction of iron ore in blast furnaces.

The objective of this study is to understand the transformation of the iron industry in South Africa from the industrial engineering perspective. Literature used for this study includes text books, organisations' reports in the public domain, published research documents, and government publications.

Archaeologists have discovered two main types of Iron Age furnace [3]: the pit furnace [4], and the shaft furnace [3]. The Iron Age economy was centred on barter trade: iron tools such as hoes, axes, and spears were used as a medium of exchange, and high purity iron was used to forge jewellery [5]. Iron Age smelting sites have been discovered in the Tugela basin [4], the Hluhluwe Game Reserve [6], Broederstoom [3], and the Marico district [3]. The wide spread of smelting sites suggests a production system that was centred on meeting the demand of the immediate community. Thus a decentralised manufacturing culture resulted in many smelting sites. Tests conducted by the Institute of Mining and Metallurgy showed the same quantity of impurities in slag samples collected from 12 different smelting sites [3]. This indicated knowledge and skill-sharing between different settlements in smelting practices and techniques. To improve production in the furnaces, inclined melting chambers were constructed [4] for easy tapping, and the melting chamber was sunk into the ground to avoid heat loss [7], [8]. The operators would use bellows to supply more air to the furnace 
to generate a faster melting rate, and a single smelting site had more than one furnace. The skill and expertise of the ancient iron-makers have been eroded by time, but the contributions of the late Iron Age generation alerted succeeding generations to the possibility of making iron and steel from native ores in South Africa.

\section{IRON AND STEEL PRODUCTION: PRE-UNION PERIOD}

This section outlines the developments in steelmaking industry prior to the establishment of the Union of South Africa in 1910.

\subsection{Iron and steel production: Before the Anglo-Boer War}

The demand for iron and steel increased in the 1880s due to the expansion of gold mines on the West Rand [9] and of the Kimberley diamond mines [10]. The immediate reaction of iron merchants was to import steel from Europe. The South African Coal and Iron Mining Company of 1882 was the first iron company to be established. The purpose of the company was to acquire the right to work in the coal, iron, iron ore, shale, lime, limestone and clay mines in the region of Dundee; but lack of capital doomed its prospects.

When a plan to construct a railway line between Lourenço Marques (Maputo) and the Transvaal was tabled, the vision was to establish a local steel industry that would supply all the steel requirements. The Transvaal Government Iron Concession was established to meet that demand; but the company was liquidated just after the completion of the project [11]. Investors' attention switched to the booming gold industry, although many believed that, like the California gold rush of 1848-1849 [12], it would soon vanish. Gold mining was more lucrative during this period, with faster returns than investments in steel. Additional challenges to the establishment of a functional iron and steel industry, as noted by Richards [13], included the lack of expertise and practical experience with steel-making operations.

\subsection{Iron and steel production: After the Anglo-Boer War}

The first attempt to smelt native ore was by Samuel Light Green in Sweetwaters in 1901. Mr Green was a former manager at Stanhope Gold Mining Company, and had relinquished his managership at the mine. Construction of the blast furnace for iron production began in 1901 with coke being prepared at the site [13], [14]. According to Mr Green's account, the first trial produced two tonnes of pig iron, and some of the samples were exhibited at the Johannesburg Empire Exhibition in 1936 [15]. The main challenge of the operations was the scarcity of limestone, which was not available locally. This disabled the production of pig iron at Sweetwaters, and the enterprise diverted its attention to the coke business [14]. The courage and vision of Green prompted the Government of Natal to set up an Industry and Tariff Commission in 1906 [16]. Commenting on the possibility of an iron industry in the colony, the commission recommended that the Government appoint an engineer of integrity to compile a comprehensive report on iron deposits in the colony to attract investors.

In the Vryheid district, a successful diamond miner, Mr Bonas, signed a contract with the Natal Government to establish an iron and steel works in the colony. In return, the Government of Natal was to purchase coal from the establishment. The Vryheid Railway Coal and Iron Company Limited Act No.55 of 1906 was passed for this purpose [13].

In 1907 Mr Dieckie and his associates established the Alverstone Iron Ore Syndicate Limited [11], [13], and experimented with surface limonite deposits with the aim of establishing an iron and steel works. A lack of funds led to the syndicate's liquidation in 1911.

Stimulated by Green's effort in Natal, in 1903 Mr Henry Wright from the colony of Transvaal acquired a concession in Magnet Heights, with conditions, to set up a blast furnace at an estimated cost of $\mathrm{£} 1$ million [17]. Wright took samples of the magnetite ore to steel masters in Middlesbrough, in the north of England, and in South Wales, but failed to convince any investor to invest in South Africa [13]. A ray of hope came as he discovered that the same type of ore - with double the amount of titanium - had been treated in France using the blast furnace route. Wright sought to export iron ore, but could not get an exemption on transportation charges between Belfast and the nearest station [11]. 
Scrap accumulation in the mines and railway industries became a problem, putting pressured on the governments of the colonies to take decisive action towards establishing a functional iron and steel industry. To investigate the scope and state of the industry, the Transvaal government set up a commission in 1907 [18]. Concerning the state of the iron and steel industry, the Transvaal Customs Commission (1907-1908) recommended the use of a blast furnace to produce iron and steel from scrap iron and from native ore that was abundant in the colony. After the commission, Transvaal mining engineer Robert Kotze released his "Memorandum re Iron and Steel Industry" in 1909 [19], [13]. Mr Kotze insisted on the capacity of the colony to meet its iron and steel requirements, given the abundance of the magnetic, hematite, ferruginous, and limonite ores in the colony. His vision was to make South Africa the dominant iron producer among its neighbours; and he proposed the construction of a blast furnace in Pretoria where there was abundant fresh water for operations. The memorandum used Australian and Canadian funding models, in which those governments supported the establishment of local iron and steel industries. The Transvaal government was to provide capital for the initial phase, raised through bounties or guarantees on the capital spent. The main challenge of the bounty system was that production had to begin before any form of government assistance was given; and this led to an integration of the bounty system and guarantees on the capital spent. The vulnerable local company needed to be protected from competition from well-established steel producers in Europe, and so Kotze recommended a monopoly system with no room for external competition. Kotze strongly objected to scrap being exported without any valueadding processing, and recommended the use of an electric furnace to treat scrap. To safeguard the scrap exports, higher railway tariffs on the transportation of scrap and a prohibitive export duty were imposed.

The Transvaal government sought the services of a steel expert, F.W. Harbord, who produced a report that was critical of the local demand for pig iron, stating that it was premature to construct a blast furnace [20]. Harbord recommended instead the use of an electric furnace to solve the crisis of scrap accumulation. The Transvaal government accepted his recommendations, and called for tenders from local firms that were interested in recycling scrap [21]. The tender was granted to the South African Steel Corporation, which had proposed the use of a Heroult furnace [17].

\subsection{Summary}

The pre-union developments are summarised in Table 1. The South African Coal and Iron Company Limited was the first iron-producing company in the history of the South African iron and steel industry. The authors have excluded other small enterprises from this study because they played little or no significant role in the evolution of the local steel industry.

\section{3}

POST-UNION DEVELOPMENTS (1910-1961)

The Union of South Africa spans the period from 31 May 1910 to 31 May 1961. This section focuses on developments in the steel industry during this period.

\subsection{Union Steel Corporation of South Africa}

The Minister of Industry and Commerce, F.R. Moor, appointed Sir Thomas M. Cullinan, William Macintosh, Charles Smith, Anthony Vilijoen, and Cornelius Hermas to be part of the Commerce and Industries Commission on 10 October 1910 [22]. The commission was to investigate the conditions of the Union industry in relation to all matters. The commission's findings were released in November 1911 [23] [14]. Concerning the iron and steel industry, the commission recommended intensive testing of native ore and the erection of a blast furnace for ore treatment. With no foreign investment, the Union Government had to reconsider the agreement between the former Transvaal government and Wright. An agreement was signed giving Wright rights to around 15000 tonnes of railways scrap [24]. Wright was supposed to establish a functional iron and steel works; and in the third year of its operations the company was to start treating local ores in viable quantities that would sustain commercial production. Wright failed to form the company within the stipulated time frame, and on 31 January 1912 the Union Steel Corporation of South Africa Limited (USCO) took over the tender [13], [25]. Some members of the House of Assembly were aggrieved about Wright's treatment and the terms granted to USCO, leading to the formation of a select committee on 16 April 1912. The committee concluded that the price of scrap to USCO was fair and that the South African Railways was to purchase its iron and steel requirements from USCO, subject to quality standards. The scrap agreement was a remedial action to mitigate the discouraging effects of Harbord's report [26]. The select committee highlighted that the agreement with USCO should be 
delayed until reasonable and satisfactory financial agreements had been made. Production began in 1913, using two open hearth furnaces fuelled by gas from Witbank coal [27].

Table 1: Summary of pre-Union developments

\begin{tabular}{|c|c|c|}
\hline $\begin{array}{l}\text { Year of } \\
\text { establishment }\end{array}$ & Name of firm & Comments \\
\hline 1882 & $\begin{array}{l}\text { South Africa Coal and } \\
\text { Iron Company Limited }\end{array}$ & $\begin{array}{l}\text { - The steel industry was under the 'gold shadow', whereby } \\
\text { the investment focus was on the gold industry with its } \\
\text { quicker and higher returns . } \\
\text { - The political landscape presented South Africa as a high- } \\
\text { risk investment area. Political crisis led to the Anglo-Boer } \\
\text { War of 1899-1902. }\end{array}$ \\
\hline 1895 & $\begin{array}{l}\text { Transvaal Government } \\
\text { Iron Concession Limited }\end{array}$ & $\begin{array}{l}\text { - Market for the concession dried up after completion of } \\
\text { the Lourenço Marques-Pretoria railway line. } \\
\text { - Poor marketing strategy. }\end{array}$ \\
\hline 1901 & $\begin{array}{l}\text { Sweetwaters Blast } \\
\text { Furnace }\end{array}$ & $\begin{array}{l}\text { - Absence of support from the government in form of } \\
\text { bounties and other financial support systems crippled } \\
\text { production. } \\
\text { - Limestone for flux purposes was not available locally. } \\
\text { - Inadequate metallurgical processing skills. }\end{array}$ \\
\hline 1903 & M H Wright Concession & - Absence of capital. \\
\hline 1906 & $\begin{array}{l}\text { Vryheid Railway Coal } \\
\text { and Iron Company }\end{array}$ & $\begin{array}{l}\text { - The main figure, Mr G.H. Bonas a successful diamond } \\
\text { miner, did not commit enough resources to establish the } \\
\text { iron and steel industry. }\end{array}$ \\
\hline 1907 & $\begin{array}{l}\text { Alverstone Iron Ore } \\
\text { Syndicate Limited }\end{array}$ & $\begin{array}{l}\text { - Did not receive the expected support from the Transvaal } \\
\text { government or British investors. }\end{array}$ \\
\hline 1909 & $\begin{array}{l}\text { Maritzburg Iron } \\
\text { Company Limited }\end{array}$ & $\begin{array}{l}\text { - Government did not provide any guarantee or protect the } \\
\text { local investment against foreign competition. }\end{array}$ \\
\hline 1910 & $\begin{array}{l}\text { South Africa Steel } \\
\text { Corporation }\end{array}$ & $\begin{array}{l}\text { - Had Transvaal government support, and had been given } \\
\text { monopoly over acquiring approximately } 15000 \text { tonnes of } \\
\text { railway scrap. }\end{array}$ \\
\hline
\end{tabular}

\subsection{Establishment of other independent iron and steel firms}

While government engagements continued, brilliant minds were progressing independently. In 1911, motivated by the demand for iron and steel products in mines, George Stott, a former blacksmith supervisor at Meyer and Charlton Gold Mine, started an open die forging enterprise [28].

Cartwright and Eaton Machine Merchants converted their company to Union Iron and Steel Works in 1911. The company set up a small plant in Benoni, and was converting railway scrap into steel bars. The principal market for the company was the railways, and in 1914, following the resignation of Eaton as a director, the company was rebranded to Dunswart Iron and Steel Works. In 1914 World War 1 broke out, and all steel imports were curtailed, thus increasing the revenue of local independent steel companies.

The Robinson Gold Mine established the Witwatersrand Cooperative Smelting Works to mitigate import cuts during World War 1 [29], [27]. The plant showed the feasibility of preparing steel shoes and dies for stamp batteries through melting discarded and worn-out shoes.

Eaton, the former director of Cartwright and Eaton, joined a syndicate to form Newcastle Iron and Steel Works Limited in 1920 to experiment on treating local iron ore [30], [11]. The company began to build a blast furnace. However, without support from Britain, and coupled with the post-war depression, construction halted. The Newcastle blast furnace was completed by USCO in 1921, and by 1926 another USCO steel plant had started production near Klip River [17].

Dunswart Works had embarked on the construction of an experimental blast furnace in Vereeniging [30]. Financial constraints forced USCO and Central Mining \& Investment Corporation to inject capital in order to complete the project, and formed Transvaal Blast Furnace Limited to oversee production at the Dunswart Vereeniging works [31]. Experimental smelting began in October 1918, 
and the pig iron produced was of an acceptable quality. An influenza epidemic broke out, and operations were halted, but Professor G.H. Stanley recommended that the company install a modern blast furnace that could produce 1000 tonnes of pig iron per week [32]. Professor Stanley discouraged the exporting of iron ore, and highlighted the capacity of the local industry to produce different grades of iron and steel to meet local demands [33].

Scaw Metals started operations in Eloff Street Extension in Johannesburg in 1924, and then acquired a 49-hectare site in Germiston to which it later relocated its works. The railway was the main market for the company; by 1956 it had become the lead supplier of cast steel bogies [34].

\subsection{South African Iron and Steel Corporation Limited}

The Municipality of Pretoria granted mining rights over certain iron ore reserves in the region to a Mr Delfos. Like his predecessors, he attempted without success to attract European investment. The European iron masters thought that South African coal could not produce the right quality of coke to treat iron ore in blast furnaces. Delfos took up the challenge, and built an experimental blast furnace in November 1917 under Pretoria Iron Mine [35]. Production began in June 1918, but it was short-lived; and production ceased towards the end of 1919 [30], [36]. Production was characterised by poor product quality, even though the feasibility experiments of treating local ores had been successful. Pretoria Iron Mines Limited continued with avenues of exploration in the iron and steel industry, and managed to secure a fixed market, supplying 50 per cent of the projected iron and steel requirements of the South African Railways [37].

To meet the 50 per cent requirement obligation, Mr Delfos, director of Pretoria Iron Mines Limited, formed a partnership with National Industrial Corporation, Anglo American, Central Mining and Investment Corporation, and Delagoa Bay Collieries. The South African Iron and Steel Corporation was formed, with Pretoria Iron Mines holding 200000 shares in the corporation. A legal battle ensued, as this was seen as a direct violation of the 1912 agreement on scrap steel with USCO [24]. A select committee was appointed to investigate USCO's complaint [38]. The committee did not deem the deal signed between Minister Burton and South African Iron and Steel Corporation binding, and recommended the establishment of a large state steel enterprise or of a private enterprise with government support.

\subsection{The Iron and Steel Industry Act of $\mathbf{1 9 2 8}$}

A continental iron manufacturer from Germany, Gutehoffnungshutte, offered the Union government some of its experts to come and conduct an in-depth analysis of the possibility of establishing a large, functional, integrated iron and steel works [35]. The commission's investigations began in February 1924 [39], and its report was completed towards the end of 1924 [40]. The original copy was in German. The unofficial translated copy that was presented to the Senate later, in 1928, had eight sections [41]. These consisted of the background to the South African industry in relation to the possibility of establishing an iron and steel works, the assets of the proposed South African Iron and Steel Corporation Limited, the raw material for the proposed works, the results of coking tests on the native coal, estimates of installation and operational costs for mining activities, an analysis of technical factors, economic and cost factors, and the report's summary. Local expert Dr F. Meyer described the survey as extraordinary work in which all aspects of the industry had been examined in an exclusively objective, scientific, and technical manner [35]. The technical commission proposed Pretoria as the most feasible site, and noted that there was a large and growing market within the Union's borders that could sustain an iron and steel works producing 150000 tonnes per annum. Mr Delfos tried to lure British investors with this technical report, but to no avail. He then shifted his attention to the Union government. Pressure was put on the government to act by both Labour Party members and by the business community. Motions were proposed in the House of Assembly between 1925 and 1926, accompanied by controversy [40]. The proposed bill was controversial in two respects:

- $\quad$ the Governor-General's authority to appoint a Board of Directors to control the company

- $\quad$ the clause that gave the government special shares.

The opposition argued that the clause was a threat to the company, as the state would interfere in the company's operations. The bill was easily passed in the House of Assembly on 10 February 1927, but was rejected by the Senate, where the opposition was in the majority. The bill was re-introduced in the Senate in October 1927, and after a lengthy examination, the bill was rejected for the second 
time on 23 March 1928 [40]. A deadlock was reached; but the constitution made provision for a joint sitting, which occurred on 30 March 1928. The bill was passed at the joint sitting, and on 14 April 1928 the Iron and Steel Industry Act (No.11 of 1928) was adopted.

The Act was intended to promote the development within the Union of iron and allied industries, and for that purpose it constituted the South African Iron and Steel Industrial Corporation Limited (Iscor) with a capital of $\mathfrak{E 3 . 5}$ million [42]. The share structure was divided into ' $A$ ' shares and ' $B$ ' shares. The group ' $A$ ' shares were all allocated to the government, which would contribute $£ 500$ 000; and the ' $\mathrm{B}$ ' shares, worth $\mathrm{f} 3$ million, were reserved for the public. Since the government had the 'A' shares, the Governor-General was to appoint four of the seven company directors and select the Chairman of the Board for the company. The ' $A$ ' shares had one vote aggregate over the ' $B$ ' shares. To strike a balance between state control and private business operations, employees who were not in the public service and the Union government had no direct influence over the routine operations of the company [42].

\subsection{South African Iron and Steel Industrial Corporation Limited}

The proclamation of the South African Iron and Steel Industrial Corporation Limited (Iscor) in the Government Gazette in June 1928 marked the eve of a massive iron and steel industry in South Africa [43]. Mr Delfos had finally entered the era he had dreamed about: his the years of singleminded endeavour had borne fruit. Dr H.J. van der Bijl landed the position of Board Chairman, with Mr Delfos as full-time Director; their Technical Assistant was Dr F. Meyer [40]. The company had gained legal status, but its woes were far from over. In Parliament the opposition declared war on Government involvement in the company. Eventually the ' $\mathrm{B}$ ' shares could not raise the expected $\mathrm{E} 3$ million, and the Government stood by its commitment to acquire a majority stake in the ' $\mathrm{B}$ ' share category. It had vowed earlier that, if the public did not subscribe the capital, it would use public funds [35]. Production began in Pretoria in 1934; the infant steel works had a capacity of 160000 ingot tonnes per annum. The local demand for iron and steel products increased such that the production figures had doubled by 1939 [44]. In 1942 a plate mill was installed at Vanderbijlpark, and by 1947 the plant was fully functional. By 1950 the corporation had the capacity to produce 1 million tonnes of liquid steel per year, with the Vanderbijlpark works being the major contributor. The Pretoria works' contribution to the annual production could not justify the selection of Pretoria as a site. Despite the Gutehoffnungshutte recommendation of Pretoria as a site, the commission's technical calculations in relation to raw materials indicated that Pretoria was not the ideal site. The total raw materials required annually to produce 132000 tonnes of rolled products was 1.03 million tonnes [41], Pretoria could supply only a seventh of that.

\subsection{The rise of the ferro alloys industry}

Dr H.J. van der Bijl pioneered the ferro alloy industry in South Africa by forming the African Metals Corporation (Amcor) Limited. The company began the production of high ferromanganese in Newcastle on 23 July 1937. The construction programme for Amcor consisted of building two electric furnaces in Vereeniging to produce ferro alloys. The first furnace was commissioned on 15 February 1942, and the production of ferro silicon began in April 1942. Through Minerals Engineering of Colorado, the Rockefeller family opened a subsidiary in South Africa known as the Minerals Engineering Company of South Africa [45]. The plant was set up in Witbank in 1957 to produce around 1.4 million tonnes of vanadium pentoxide annually [46].

\subsection{Anglo American investments in the steel industry (Highveld Steel Development Company)}

The Anglo American Corporation of South Africa acquired two-thirds of the shares in the Minerals Engineering Company in 1959, and it was rebranded as the Transvaal Vanadium Company Limited in August 1960 [47]. The Highveld Steel Development Company was established in 1960, and began to experiment with the viability of processing titaniferous magnetite ore to produce liquid pig iron [46]. The pilot plant was set up in Witbank and used a new smelting technique of a four-stage electrical process. Recording success in the pilot experiments, Anglo America sought to construct a full-scale plant, and turned to Iscor for a joint venture. The proposal included a provision that a foreign steel company would provide the capital; but the Iscor board rejected it [48].

\subsection{Summary}

Figure 1 displays the progress of the iron and steel industry in the Union of South Africa in terms of production output [49]. Commercial production of pig iron was begun by USCO in Newcastle and Klip River in 1926. Prior to the USCO blast furnace, steel production was from scrap, which was abundant 
in the railways and mines. Production began at the Iscor works in Pretoria in 1934, and local pig iron production and steel production increased significantly until 1961.

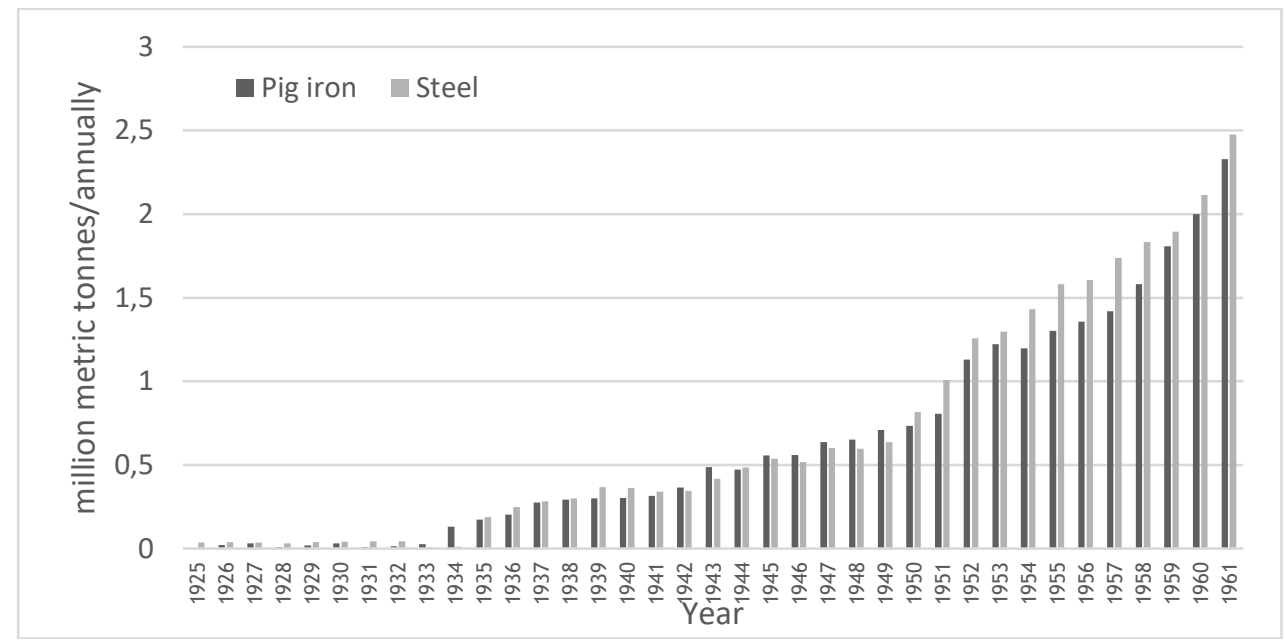

Figure 1: Pig iron and steel production, 1925-1961 [49]

\section{$4 \quad$ IRON AND STEEL INDUSTRY IN THE REPUBLIC OF SOUTH AFRICA}

In May 1961 the Union of South Africa became the Republic of South Africa. In this section, the focus is on major developments in the iron and steel industry in the Republic of South Africa. The section covers significant independent enterprises, Iscor's expansions, and the Highveld Steel Development Company's expansions.

\subsection{Independent steel enterprises}

Despite the heavy presence of the Anglo American Corporation and Iscor, the Cape Gate (Pty) Limited was established in 1962 through the purchase of a small netting plant [50]. The company established the Sharon Wire Mill in 1967 to produce uncoated and galvanised wire, welded mesh, diamond mesh, barbed wire, and field fence, among other products. In 1975 the company rolled out the Davesteel division to produce wire rod, rebar, and rounds; and in 1980 the company ventured into the first melting operations. Another private enterprise was CISCO, established in 1965 but acquired by Iscor in 1973 [51]. The most recent enterprise to sprout in South Africa iron and steel industry is Unica Iron and Steel (Pty) Limited, began production in 2006 [52].

\subsection{Iscor's expansions}

The plan to establish a third works for Iscor in Newcastle was tabled in 1969. The choice of that location gave Iscor the chance to develop a major agglomeration outside Gauteng. The development came with the modern optimism of creating new production spaces in the Republic other than in Gauteng [53]. Iscor began erecting an integrated iron and steel works through a sub-contractor - the Gutehoffnungshutte Company $(\mathrm{GHH})$ - to install a modern blast furnace capable of producing 4500 tonnes of pig iron a day [44]. The integrated steel works and long products mill construction was completed in 1976.

In 1973, Cape Town Iron and Steel-works (Pty) Limited (CISCO) became a wholly-owned subsidiary of Iscor [51]. In 1982 CISCO installed a new melt-shop with a capacity of 100000 tonnes of billet per annum; and further upgrades in 1989 increased the production capacity to 160000 tonnes of billet and 66000 tonnes of reinforcing bar per annum.

In 1988 Iscor embraced the technology of the Corex process - an alternative route for reducing iron ore using non-coking coal as a source of energy [54] - and the first commercial Corex unit in the world began production at Iscor in Pretoria [55]. The plant had a production capacity of 300000 tonnes of liquid iron per annum, and initially operated on full capacity using sponge iron. When using iron ore as a raw material, the plant could operate at 75 per cent of its designed capacity. 
Following the privatisation of Iscor, the company was listed on the Johannesburg Securities Exchange on 8 November 1989. In 1991, Iscor gained full control of the USCO steel works and named the facility Iscor Vereeniging Works [56].

The Saldanha steel plant operation was commissioned in 1998, as a niche operation. The plant served as a steel export hub for Iscor [57]. The aging Pretoria Steel Works was decommissioned in 1997. In 2001, Iscor transferred its shares to Kumba Resources Limited, and in late 2004 LNM Holdings acquired 51 per cent of Iscor Limited. In June 2006 Mittal Steel merged with Arcelor, creating ArcelorMittal, the largest steel company in the world, thus placing all Iscor operations under ArcelorMittal South Africa (AMSA) [58].

\subsection{Highveld Steel Development Company expansions}

The trials conducted by Highveld Steel Development Company Limited on the viability of processing titaniferous magnetite ore to produce liquid pig iron and vanadium-bearing slag were a success [59]. In 1964, Anglo American acquired Scaw Metals [34], and production began at Highveld. The company was rebranded as the Highveld Steel and Vanadium Corporation (HSVC). By 1966 HSVC was the leading vanadium producer globally [46]. Transalloys (Pty) Limited (Transalloys) had been successful in producing manganese alloys; subsequently in 1965 HSVC acquired 65 percent of Transalloys. In 1985 Transalloys became a wholly-owned subsidiary of HSVC. In the same year (1985) sHSVC took over the manufacturing of drums, pails, and crown closures by acquiring Rheem South Africa (Pty) Limited (Rheem). Previously, in 1978, HSVC had acquired shares in Rand Carbide, which had begun production in Germiston in 1918. Despite the privatisation of Iscor in 1989, HSVC's expansion became inevitable. In 1991 the company acquired Middleburg Steel and Alloys, and to extend its reach, the company had shares in Hochvanadium Holdings, operating in Austria. The turn of the millennium brought new polices for Anglo American: there was a shift away from the iron and steel industry, and the group embarked on a process of portfolio trimming. In 2002 the company offloaded 64 per cent of its shares in Columbus Stainless (Pty) Limited, and retained only 12 per cent in the entity. In 2003 Highveld sold 50 per cent of its shares to South Africa Japan Vanadium (Pty) Limited. In 2006, Anglo American plc sold its main stake to the EVRAZ Group, and by 2010, HSVC had been rebranded as EVRAZ Highveld Steel and Vanadium [60].

\subsection{Summary}

Between 1962 and 1981, the production of pig iron tripled from approximately 2.5 million metric tonnes to more than eight million tonnes, as shown in Figure 2 [61] [49]. This was mainly due to the expansion plans of Iscor and the establishment of HSVC in the 1960s. With limited imports and exports of pig iron, a greater percentage of local pig iron went through reduction processes to produce steel. The margin between production levels of pig iron production and steel production began to increase from 1983 onwards. This margin is explained by the establishing of new enterprises that produced steel via the mini-mill route, using scrap iron. The mini-plants that operated during the period include Scaw Metals, CISCO, Cape Gate Private Limited, Unica, and AMSA mini-mill plants in Vereeniging and Vanderbijlpark.

Since 2006, the South African iron and steel industry has faced stiff challenges, which have included lower commodity prices and external competition through imports. Steel production dropped rapidly from 9.7 million metric tonnes in 2006 to 6.55 million metric tonnes in 2014 . This amounts to a onethird decrease in local steel production. 


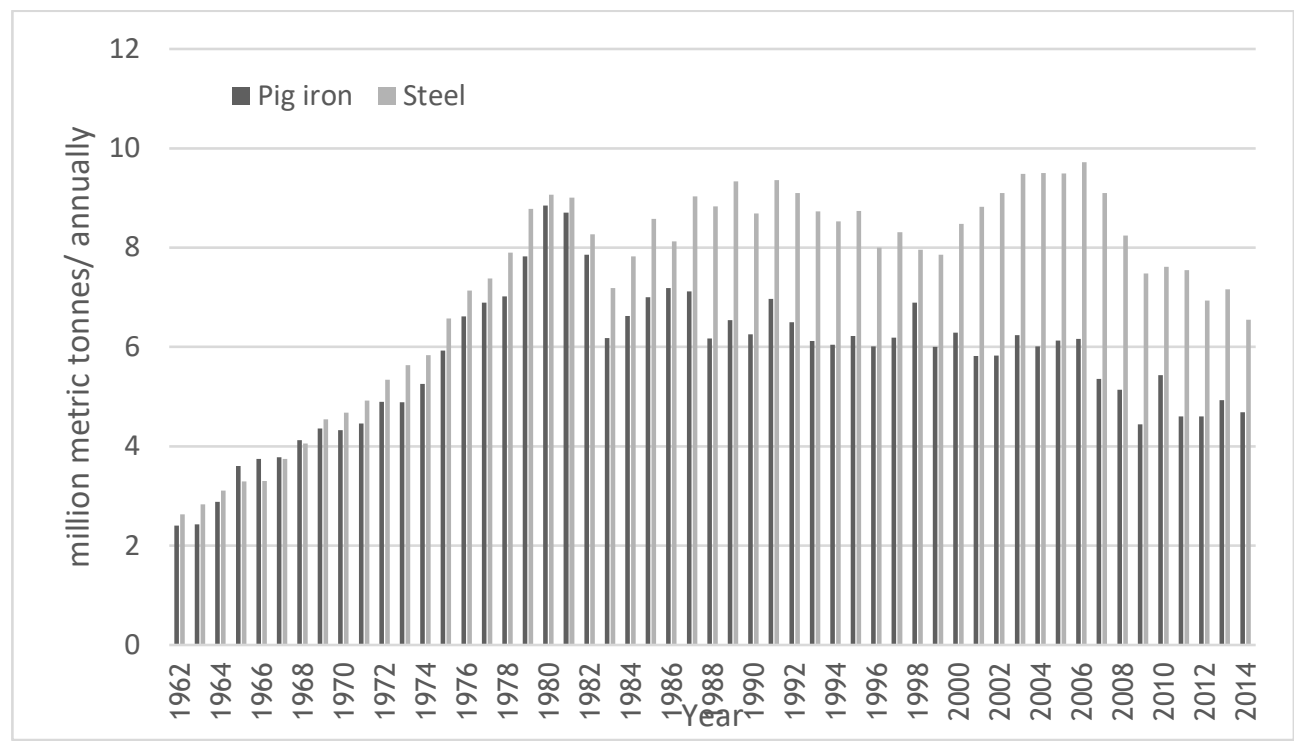

Figure 2: Pig iron and steel production, 1962-2014 [61] [49]

\section{CURRENT STATE OF THE INDUSTRY}

ArcelorMittal South Africa (AMSA) is the largest iron and steel company in South Africa, with an annual production capacity of 6.1 million tonnes of liquid steel [62]. AMSA owns five plants: three integrated steelworks in Vanderbijlpark, Newcastle, and Saldanha, and two plants producing steel through the mini-mill route in Vereeniging and Vanderbijlpark.

Scaw Metals Group, Columbus Stainless Private Limited, Cape Gate Private Limited, South Africa Steelworks, and Unica Iron and Steel Private Limited produce steel products through the mini-mill route.

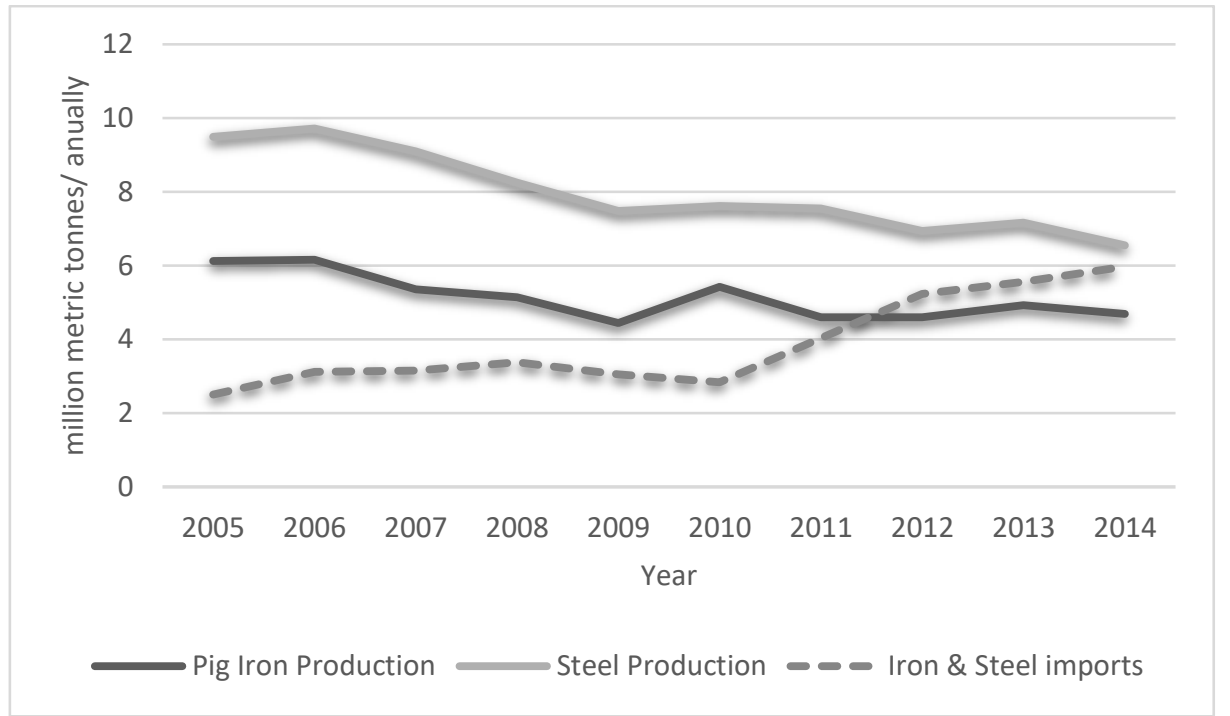

Figure 3: Pig iron and steel production against iron and steel imports, 2005-2014 [61]

The one-third decrease in steel production in the space of nine years - from a production peak of 9.7 million [61] metric tonnes in 2006 - raises the alarming prospect of the extinction of South Africa's iron and steel industry, as shown in Figure 3. If the trend were to continue, the South African iron and steel industry would cease operations within two decades. 
At the same time, imports of iron and steel products are on the rise, as also shown in Figure 3 . In 2010 iron and steel imports - including semi-finished and finished steel products, ingots and semis, long products, flat products, tubular, direct reduced iron, and indirect imports of steel - were at 2.8 million metric tonnes. Imports increased by 113 per cent to 5.98 million metric tonnes in just four years. Quality affordable steel imports pose a great threat to the continued existence of the South African iron and steel industry. Local steel producers face immense competition, and the results are inevitable: CISCO stopped operations in 2009, as did the AMSA Vanderbijlpark mini-mill plant in 2012 and the AMSA Vereeniging mini-mill plant in 2015; and EVRAZ HSVC closed its doors in 2016.

Since industrial engineering is focused on improving the production of quality products at competitive prices, the next section examines how industrial engineers contribute to published research on the local iron and steel industry.

\section{APPLICATION OF INDUSTRIAL ENGINEERING TECHNIQUES IN IRON AND STEEL PRODUCTION}

Ngetich and Moll [63] have portrayed industrial engineering (IE) as a discipline that is based on knowledge and information and built on five pillars: enterprise engineering, systems engineering, operations management, applied industrial engineering, and engineering management. Enterprise engineering focuses on engineering an enterprise holistically through the application of industrial engineering principles on every operational level of the organisation [63]. Systems engineering is the systematic approach to developing and operating systems through the identification of system objectives, then aligning subcomponents' goals with the main objective. Operations management focuses on systematically improving organisational operations such as supply chain management [64]. [63]. Engineering management applies engineering techniques and coordinates the synergy of employees in business practice with the objective of accomplishing organisational goals and objectives [65].

This section focuses on the progressive application of IE techniques in the iron and steel industry in South Africa. A survey of publications by industrial engineers in the iron and steel industry was conducted through a search of the databases of the official promoter of industrial engineering research in South Africa, the South African Institute of Industrial Engineering (SAIIE). The databases include SAIIE conference proceedings from 2009 to 2016 and issues of the South African Journal of Industrial Engineering (SAJIE) from 1987 to 2016.

The study is aware that IE research into iron and steel production is not published only in the SAIIE or SAJIE databases; but the aim of the exercise is to survey databases that are predominantly related to IE. The period reviewed was divided into three phases: 1987-1996, 1997-2006, and 2007-2016. The results of the survey are shown in Table 2.

Table 2: Published research on application of IE techniques in iron and steel production

\begin{tabular}{|c|c|c|c|c|}
\hline $\begin{array}{l}\text { Phase of } \\
\text { analysis }\end{array}$ & $\begin{array}{l}\text { Number } \\
\text { published }\end{array}$ & $\begin{array}{c}\text { Year of } \\
\text { publication }\end{array}$ & Title of paper & $\begin{array}{l}\text { Sub-discipline } \\
\text { focus }\end{array}$ \\
\hline $\begin{array}{l}1987- \\
1996\end{array}$ & 1 & 1993 & $\begin{array}{l}\text { Reducing inventory holding costs for } \\
\text { consumable items in a large steelworks } \\
{[66]}\end{array}$ & $\begin{array}{l}\text { Inventory } \\
\text { management } \\
{[66]}\end{array}$ \\
\hline $\begin{array}{l}1997- \\
2006\end{array}$ & 1 & 2001 & $\begin{array}{l}\text { Investigation of the maintenance } \\
\text { organisation for hot rolling mills [67] }\end{array}$ & $\begin{array}{l}\text { Maintenance } \\
\text { management } \\
{[67]}\end{array}$ \\
\hline $\begin{array}{c}2007- \\
2016\end{array}$ & 3 & 2013,2014 & $\begin{array}{l}\text { Investigating the impact of poor } \\
\text { utilisation of quality management } \\
\text { system in a South African foundry [68], } \\
\text { The application of PDSP cycle to solve } \\
\text { production challenges at the electric } \\
\text { arc furnaces [69], Exploring the need } \\
\text { for planned maintenance in response to } \\
\text { low productivity at a heavy steel } \\
\text { manufacturer [70] }\end{array}$ & $\begin{array}{l}\text { Quality } \\
\text { management } \\
\text { [68], Production } \\
\text { improvement } \\
\text { [69], } \\
\text { Maintenance } \\
\text { management } \\
\text { [70] }\end{array}$ \\
\hline
\end{tabular}

From 1987 to 2016, only five research papers related to iron and steel production had been published by SAIIE publications. Despite the successful evolution of the iron and steel industry in South Africa, published research input from local IE researchers is lagging behind. This finding supports that of 
van Dyk [71] on a review of South African IE, which found that few industrial engineers are employed in the South African iron and steel industry.

\section{CONCLUSION}

The successful transformation of South Africa's iron and steel industry is attributed to the vision of its pioneers and supporting legislation. The passing of the Iron and Steel Industry Act in 1928 marked the beginning of a prosperous era for the South African iron and steel industry. The entry of Anglo American in 1960, through the Highveld Development Corporation, stimulated competition between the major actors in the industry, leading to the increased production of pig iron and steel, as shown in Figure 4.

To date, key players in the South African iron and steel industry include AMSA, Scaw Metals Group, Cape Gate (Pty) Limited, Columbus Stainless (Pty) Limited, South Africa Steelworks, and Unica Iron and Steel (Pty) Limited. With stiff competition from external iron and steel producers, local iron and steel production has been rapidly decreasing since 2005, as shown by the trends in Figure 4 . The contribution of industrial engineers to the South African iron and steel industry is also very limited, judging from the survey of publications produced by SAIIE and of SAJIE databases.

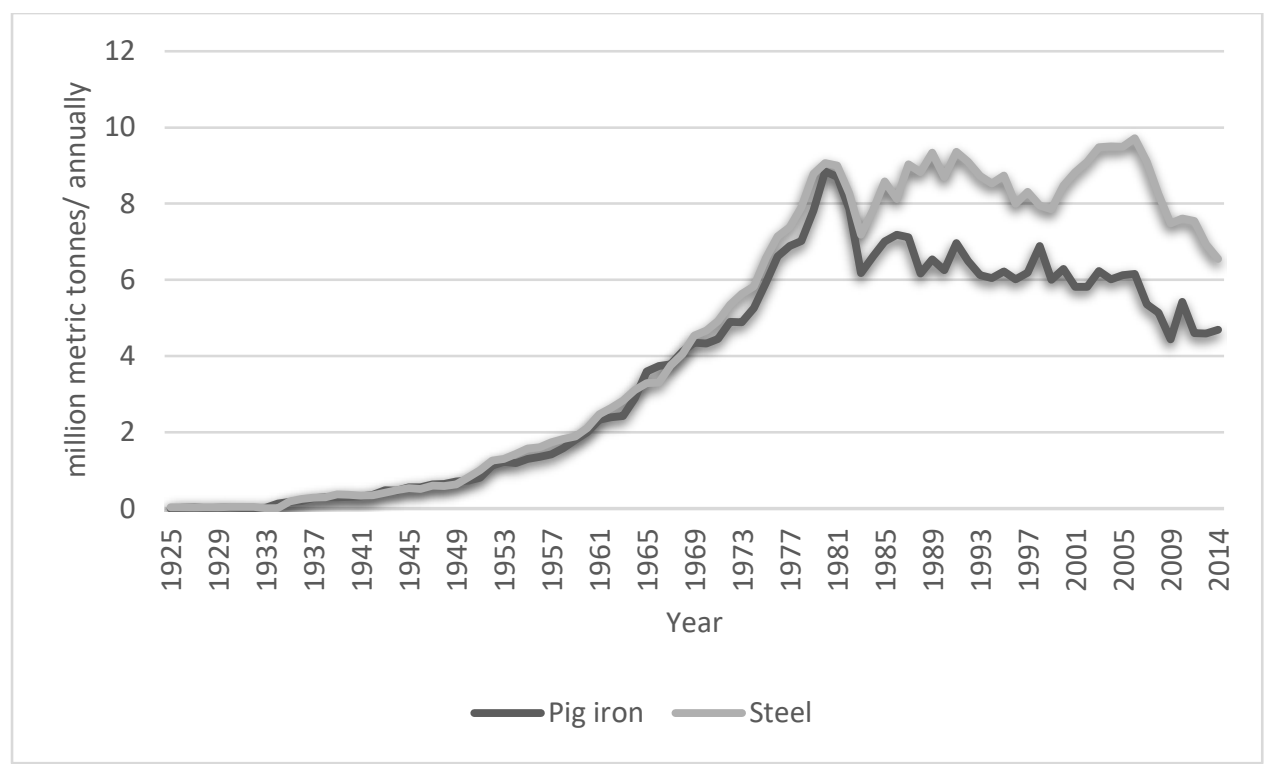

Figure 4: Production of pig iron and steel in South Africa, 1925-2014 [61]

\section{REFERENCES}

[1] Huffman, T. N. (2007). Handbook to the Iron Age: The archaeology of pre-colonial farming societies in Southern Africa., Scottsville: University of KwaZulu-Natal Press.

[2] Mason, J. R. (1974). "Background to the Transvaal Iron Age - New discoveries at Olifantspoort and Broederstroom," Journal of the South African Institute of Mining and Metallurgy, vol. 76, no. (6), pp. 211216.

[3] Friede, H. \& Steel, R. (1985). "Iron Age smelting furnaces of the Western/Central Transvaal -- Their structure, typology and affinities," The South African Archaeological Bulletin, vol. 40, no. (141), pp. 4549.

[4] Maggs, T. (1982). "Mabhija: Pre-colonial industrial development in Tugela Basin," Annals of the Natal Museum, vol. 25, no. (1), pp. 123-141.

[5] Klapwijk, M. (1974). "An analysis of Bantu made iron implements from the Letaba District," Journal of the South African Institute of Mining and Metallurgy, vol. 74(, no. 6), pp. 265-267.

[6] Hall, M. (1980). "An iron smelting in the Hluhluwe Game Reserve, Zululand," Annals of the Natal Museum, vol. 24, no. (1), pp. 165-175.

[7] Van Hoepen, E. \& Hoffman, A. (1935). "The remains of Buispoort and Braklaagte northwest of Zeerust," Explore Inge of the National Museum, vol. 2, no. (1).

[8] Campbell, J. (1822). Travels in South Africa, being a narrative of a second journey in the interior of that country., London: Francis Westley Stationers Court. 
[9] Cookhead, P. J. (2013). The East Rand: A geological analysis of the transition of the economic base of the region from gold mining to manufacturing and its effects upon future economic and social development., Johannesburg: University of the Witwatersrand Press.

[10] Fair, T. J. \& Mallows, E. W. (1959). "The Southern Transvaal: An emerging metropolitan complex in Africa," The Town Planning Review, vol. 30, no. (2), pp. 125-138.

[11] Drake, M. F. (1971). The iron and steel, metal and engineering industry in the Pretoria-WitwatersrandVereeniging Region., Johannesburg: Witwatersrand University Press.

[12] Holliday, J. S. (2015). The world rushed: The California gold rush experience., Oklahoma: University of Oklahoma Press.

[13] Richards, C. S. (1940). The iron and steel industry in South Africa., Johannesburg: Witwatersrand University Press.

[14] Meyer, F. (1952). "The development of the iron and steel industry in South Africa," The South African Journal of Economics, vol. 20, no. (2), pp. 101-112.

[15] Robinson, J. (2003). "Johannesburg's 1936 Empire Exhibition: Interaction, segregation and modernity in a South," Journal of Southern African Studies, vol. 29, no. (3), pp. 759-789.

[16] Natal Government Gazette. (1906). "Report of Industries Commission." Pietermaritzburg: Times Printing and Publishing Company.

[17] Lewis, I. (1926). The iron and steel industry of South Africa., Cape Town: Cape Times Limited.

[18] Customs and Industries Commission. (1908). "Transvaal Report of the Customs and Industries Commission." Pretoria: Government Printing and Stationery Office.

[19] Kotze, R. N. (1909). "Memorandum by the Government Mining Engineer of the Transvaal re iron and steel industry," Pretoria: Government Printing and Stationery Office.

[20] Harbord, F. W. (1980.) "Transvaal Mines Department report on the manufacture of iron and steel in Transvaal, 1910." Pretoria: Government Printing and Stationery, 1910.

[21] Transvaal Government Gazette. (1910). "Department of Mining Transvaal Government," Transvaal Government Gazette, Volume 32, 4 February.

[22] Department of Commerce and Industries. (1910). "Commerce and Industries Commission," Union of South Africa Government Gazette, p. 187, 14 October, p. 187.

[23] Commerce and Industries Commission. (1912.) "Report on Commerce and Industries Commission." Pretoria: Government Printing and Stationery Office.

[24] Department of Railways and Harbours. (1912). "Agreement in Connection with the purchase of scrap from the government," Union of South Africa Government Gazette, 20 February, p. 1196.

[25] Leigh, R. L. (1964). Vereeniging History, Johannesburg: Courier Gazette Publishers (PTY) Limited.

[26] Select Committee 9. (1912). "Select Committee on the Scrap Iron Agreement." Pretoria: Government Printing and Stationery.

[27] Stanley, G. H. (1917). "Iron and steel in the Union of South Africa: Existing Plants," South African Journal of Industries, vol. 1, no. (4), pp. 296-320.

[28] George Stott and Company. (2016). “Company History," 2016. [Online]. Available: http://www.geostott.com/index.php/about-george-stott/history. [Accessed 31 May 2016].

[29] Scott, P. (1951). "The iron and steel industry of South Africa," Geographical Association, vol. 36, no. (3), pp. 137-149.

[30] Stanley, G. H. (1920). "Manufacturing iron and steel in the Union: An account of what is being done at the present time," South African Journal of Industries, vol. 3, no. (7), pp. 883-888.

[31] Select Committee. (1927). "Select Committee on the Iron and Steel Industry Bill report." Pretoria: Government Printers and Stationery Office.

[32] Stanley, G. H. (1920). "Iron and steel in the Union of South Africa: The technical aspect," South African Journal of Industries, vol. 3, no. (7), pp. 627-640.

[33] Stanley, G. H. (1920). "Manufacturing of iron and steel in the Union: Economic Aspect," South African Journal of Industries, vol. 3, no. (7), pp. 398-406.

[34] Scaw Metals Group. (2016). "Scaw"s History," 2014. [Online]. Available: http://www.scaw.co.za/Pages/Scaw-history.aspx. [Accessed 27 June 2016].

[35] Verkouteren, M. I. (1927). The iron and steel industry, Pretoria: Facts versus interpretation, reason versus impulse, Cape Town: Cape Times Limited.

[36] Department of Mines and Industries. (1920). “Annual Report for the year ending 31 December 1919." Pretoria: Government Printing and Stationery.

[37] South Africa Railways and Harbours. (1920). “Agreement with Pretoria iron mine.," Cape Town: Limited Government Printers, Cape Town.

[38] Select Committee on Railways and Harbours. (1920). "Seventh Report of the Select Committee on Railways and Harbours", Pretoria: Government Printers and Stationery Office.

[39] Van der Byl, H. J. (1929). "The South African iron and steel industry: Its development and possibilities," Royal Society of Arts, vol. 77, no. (3984), pp. 500-518.

[40] ISCOR Limited. (1953). Steel in South Africa: The story of the beginnings of the steel industry in South Africa, the events which led to the incorporation of ISCOR twenty-five years ago, its development and effect on the industrial progress of the country since that time., Pretoria: South African Iron and Steel Industrial Corp.

[41] Select Committee 1. (1928). "Unofficial translation Report by the Commission of Experts of the Gutehoffnungshutte on the mining, iron and steel works." Pretoria: Government Printing and Stationery Office. 
[42] Union of South Africa. (1928). "The Iron and Steel Industry Act of 1928 (No.11)," in Statutes of the Union of South Africa., Pretoria:, Government Printer, pp. 160-172.

[43] Ministry of Mines and Industries. (1928). "South African Iron and Steel Industrial Corporation Proclamation," Union of South Africa Government Gazette, p. 459, 1 June, p. 459.

[44] Weston, M. \& White, D. (1975). ISCOR: YSKOR., Johannesburg: Thomson Publications.

[45] Rohrmann, B. (1985). "Vanadium in South Africa," Journal of the South African Institute of Mining and Metallurgy, vol. 85(, no. 5), pp. 141-150.

[46] Highveld Steel and Vanadium Corporation Limited. (2000). “Annual Report.," Anglo American plc group, Johannesburg: Anglo American plc.

[47] Bassan , J., Curr, T. R. \& Gerike, W. A. (2007.) "South Africa's ferro alloys industry - Present status and future outlook.," Randburg.

[48] Fine, B. \& Rustomjee, Z. (1995). "Afrikaner Nationalism, Anglo American and Iscor: The formation of Highveld Steel \& Vanadium Corporation 1960-1970,” Business History, vol. 37, no. (3), pp. 111-114.

[49] Mitchell, B. R. (1998). International historical statistics: Africa, Asia \& Oceania., London: Macmillan Reference Limited.

[50] Cape Gate (Pty) Limited. (2016). “Cape Gate Group Of Companies- About Us,” 2016. [Online]. Available: http://www.capegate.co.za/aboutus.asp. [Accessed 29 June 2016].

[51] Cisco - Cape Town Iron and Steel Works. (2016). "CISCO - History," 2015. [Online]. Available: http: //cisco.co.za/corporate/history/. [Accessed 28 June 2016].

[52] Unica Iron and Steel Private Limited. (2016). “Home.," 2016. [Online]. Available: http://www.unica.co.za/unicaironsteel/index.htm. [Accessed 14 October 2016].

[53] Todes, A. E. (2001). "Newcastle: The development of a model apartheid town and beyond," South African Geographical Journal, vol. 83, no. (1), pp. 69-77.

[54] Iscor Limited. (1989). “Iscor irons out Corex process," Steel Times International, vol. 13, no. (3), pp. 1213.

[55] Usachev, A. B., Romenets, V. A., Lekherzak, V. E. \& Balasanov, A. V. (2002). “Modern processes for the coke-less production of iron.," Metallurgist, vol. 46, no. (3), pp. 117-130, 2002.

[56] ArcelorMittal South Africa. (2016.) “Introduction to ArcelorMittal South Africa Vereeniging Works,” 2016. [Online]. Available: www.arcelormittalsa.com/Portals/0/The-History-of-ArcelorMittal-South-Africa. [Accessed June 28 2016].

[57] ArcelorMittal South Africa. (2016). "Saldanha Works Overview," 2016. [Online]. Available: http://southafrica.arcelormittal.com/Operations/SaldanhaWorks/Overview.aspx. [Accessed 29 June 2016].

[58] ArcelorMittal South Africa. (2016) “Company's History," 2016. [Online]. Available: http://southafrica.arcelormittal.com/Whoweare/OurHistory.aspx. [Accessed 29 June 2016].

[59] Steinberg, S. W., Geyser, W. \& Nell, J. (2011). "The history and development of the pyrometallurgical processes at Evraz Highveld Steel \& Vanadium," Journal of the South African Institute of Mining and Metallurgy, vol. 111, no. (10), pp. 705-710.

[60] Evraz Highveld Steel and Vanadium Limited. (2014). “Evraz Highveld Steel and Vanadium Limited: History," 2014. [Online]. Available: http://www.evrazhighveld.co.za/ highveldgrouphistory.asp. [Accessed 29 June 2016].

[61] Worldsteel Association. (2015). Steel Statistical Yearbook., Brussels: World Steel Association.

[62] ArcelorMittal South Africa. (2016). "Capacity for ArcelorMittal South Africa Plants," ArcelorMittal South Africa Factor Report, pp. 14-15, 31 May 2016, pp. 14-15.

[63] Ngetich, W. K. \& Moll, C. M. (2013). “An investigation of industry expectations of industrial engineering graduates: A case study of graduate development programmes in South African universities," South African Journal of Industrial Engineering, vol. 24, no. (3), pp. 125-138.

[64] Kumar, S. A. \& Suresh, N. (2009). Operations Management., New Delhi: New Age International Private Limited.

[65] IE Department Stellenbosch University. (2013). “Prospective postgraduates.," 2013. [Online]. Available: http://ie.sun.ac.za/prospective-postgraduates/. [Accessed 18 October 2016].

[66] Adams, A. R. \& Petrarolo, D. (1993). "Reducing Inventory holding costs for consumable items in large steelworks," South African Journal of Industrial Engineering , vol. 7, no. (1), pp. 1-11.

[67] Pretorius, P. K. \& Visser, J. K. (2001). "Investigation of the maintenance organisation for hot rolling mills," South African Journal of Industrial Engineering , vol. 12, no. (2), pp. 25-38.

[68] Mpanza, Z., Nyembwe, D., \& Nel, H. (2013). "Investigating the Impact of poor utilisation of quality management system in a South African foundry," in SAIIE25 Proceedings, Stellenbosch.

[69] Mufamadi, L. \& Hattingh, T. S. (2013). "The application of the PDSA cycle to solve production challenges at the electric-arc furnaces," in SAIIE25 Proceedings, Stellenbosch, 2013.

[70] Hartmann, D., Malaba, T. M., \& C. Saasa, C. (2014). "Exploring the need for planned maintenance in response to low productivity at a heavy steel manufacturer," in SAIIE26 Proceedings, Muldersdrift.

[71] Vvan Dyk, L. (2014). "A census of South African industrial engineers, based on data extracted from Linkedin," in SAlIE26 Proceedings, Muldersdrift, 2014. 